\title{
MODEL EKONOMI-EKOLOGI BERDASARKAN WTP PENGUNJUNG-WTA MASYARAKAT LOCAL DALAM PENGELOLAAN DESTINASI WISATA GUNUNG API BAWAH LAUT MAHENGETANG, KABUPATEN SANGIHE
}

\author{
Paulus Adrian Pangemanan \\ Gene H.M. Kapantouw
}

\begin{abstract}
Continuing management of tourist destinations, integrating economic and ecological aspects, and involving quadrohelical roles: local communities, tourism businesses, government and universities. This research develops a tourism destination management model that integrates economic and ecological development based on visitor willingness to pay (WTP) attachment with willingness to accept (WTA) of local community, supported by business actor role and government. Colleges play a role in identifying ecological and economic elements, analyzing and formulating alternative development activities that ensure economic improvement for local communities and resource sustainability (natural, socio-cultural) to improve the destination's life cycle. The purpose of this research is to manage the role of quadrohelical tourism in evaluating, developing economic programs / activities for the surrounding community, by prioritizing the sustainability of resource ecosystem. This research was conducted for 10 months in the area of Mahengetang submarine volcano in Sangihe District. This study focuses on identifying existing conditions of economic and ecological elements, analysis and formulation of alternative activities for economic and ecological improvement based on indicators (WTP-WTA). Destination management model based on WTP-WTA with integrated role of quadrohelical system can be adapted and developed in other destination, or in other resource utilization.
\end{abstract}

Keywords: tourist destinations, economy-ecology, WTP-WTA,

\begin{abstract}
ABSTRAK
Pengelolaan berkelanjutan destinasi wisata, mengintegrasikan aspek ekonomi dan ekologi, serta melibatkan peran kuadroheliks: masyarakat lokal, pelaku usaha wisata, pemerintah dan perguruan tinggi. Penelitian ini mengembangkan model pengelolaan destinasi wisata yang mengintegrasikan pengembangan ekonomi dan ekologi berdasarkan persesuaian item (indikator) willingness to pay (WTP) pengunjung dengan willingness to accept (WTA) masyarakat local, yang didukung peran pelaku usaha dan pemerintah. Perguruan tinggi berperan mengidentifikasi unsur ekologi dan ekonomi, menganalisis dan merumuskan alternative kegiatan pengembangan yang menjamin peningkatan ekonomi bagi masyarakat lokal dan kelestarian sumberdaya (alam, sosial-budaya) untuk peningkatan life cycle destinasi. Tujuan penelitian ini adalah terpolanya peran kuadroheliks pariwisata dalam mengevaluasi, mengembangkan program/kegiatan ekonomi bagi masyarakat sekitar, dengan mengedepankan kelestarian ekosistem sumberdaya. Penelitian ini dilaksanakan selama 10 bulan di wilayah destinasi gunung api bawah laut Mahengetang di Kabupaten Sangihe. Penelitian ini berfokus pada identifikasi kondisi eksisting unsur ekonomi dan ekologi, analisis dan perumusan alternative kegiatan untuk peningkatan ekonomi dan ekologi berdasarkan indikator (WTP-WTA). Model pengelolaan destinasi berdasarkan WTP-WTA dengan peran terintegrasi sistem kuadroheliks dapat diadaptasi dan dikembangkan di destinasi lain, atau dalam pemanfaatan sumberdaya alam lainnya.
\end{abstract}

Kata kunci: destinasi wisata, ekonomi-ekologi, WTP-WTA, kuadroheliks 


\section{PENDAHULUAN}

\section{Latar Belakang}

Gunung api bawah laut Mangehetang terletak di pulau Mahengetang, Kecamatan Tatoareng Kabupaten Sangihe. Kecamatan Tatoareng terkenal kaya dengan obyek wisata bawah laut (spot diving) di p. Para, p. Nitu, p. Kahakitang, p. Kalama (Sangihe dalam angka, 2013). Spot diving gunung api bawah laut Mahengetang merupakan icon dari wisata pantai dan bawah laut di Tatoareng. Wisata bawah laut di Tatoareng juga ditunjang obyek wisata laut (spot diving di. p. Batunderang, p. Mendaku dan p, Bebalang - wilayah kecamatan Manganitu Selatan) yang secara ekologis masih merupakan satu kesatuan). Kekayaan dan keragaman obyek wisata laut di kawasan ini berpotensi untuk meningkatkan kunjungan, investasi maupun kegiatan ekonomi masyarakat. Data dari Dinas Kebudayaan dan Pariwisata Kabupaten Sangihe (BPS Kabupaten Sangihe), menunjukkan peningkatan signifikan jumlah kunjungan dari tahun $2011 \quad(20.490$ kunjungan) ke tahun $2012 \quad(33.580$ kunjungan) (Sangihe dalam angka, 2013) diduga kuat jumlah kunjungan ini meningkat terus selama empat tahun terkakhir, terkait dengan layanan transportasi kapal cepat (rute Manado-Tahuna) yang menyinggahi kecamatan Tatoareng 2 kali seminggu (4 kali bolak-balik). Jumlah kunjungan wisatawan di kawasan Tatoareng dipastikan melebihi data yang tercatat resmi di BPS Kabupaten (berdasarkan data tamu hotel atau wisatawan tercatat di agen perjalanan, karena banyak pengunjung yang tidak terus ke kota Tahuna (langsung turun di Tatoareng - dalam rute perjalanan Manado-Tahuna). Akses ke Tatoareng dari ibu kota Kabupaten - Tahuna cukup lancar menggunakan berbagai jenis transportasi laut. Jarak ibu kota kecamatan Tatoareng (Kahakitang) dari ibukota Kabupaten (Tahuna) 33,67 mil, ditempuh dengan kapal cepat dalam waktu 45 - 55 menit. Menggunakan transportasi laut lainnya membutuhkan waktu 1,5-2 jam. Keragaman dan daya tarik wisata bahari di Kecamatan
Tatoareng dan sekitarnya belum dibarengi dengan ketersediaan sarana dan fasilitas yang memadai. Di wilayah kecamatan Tatoareng hanya ada satu homestay yakni homestay Mahengetang, menyediakan 12 kamar. Pengunjung yang menginap di wilayah ini menyewa kamar yang disediakan di rumah penduduk - merupakan potensi peningkatan pendapat masyarakat setempat. Hasil survey yang dilakukan tim pengusul tahun 2016 menyimpulkan posisi pengelolaan kawasan wisata gunung api bawah laut Mahengetang dan sekitarnya dalam life cycle destinasi masih berada dalam fase eksplorasi.

Kebijakan tol laut dan berbagai prioritas pembangunan kemaritiman, sangat potensial mendorong peningkatan signifikan kunjungan dan berbagai aktivitas ekonomi di kawasan ini. Berbarengan dengan peningkatan aktivitas wisatawan dan kegiatan ekonomi, degradasi sumberdaya dan kerusakan lingkungan akan meningkat. Peningkatan laju pembangunan/pemanfaatan sumberdaya destinasi wisata bahari yang rawan (fragile resources), perlu diantisipasi dengan mengendalikan dan perlindungan sumberdaya. Konsep pembangunan berkelanjutan semakin mengemuka dalam pengelolaan destinasi wisata, dengan menekankan keseimbangan tiga aspek pembangunan yakni ekonomi, social, dan lingkungan (Koens et al, 2009; Barkin, 2003). Khusus dalam pengelolaan destinasi wisata, konsep ekowisata merupakan alat (tool) dari pembangunan berkelanjutan yang mempertemukan pertumbuhan ekonomi dengan pelestarian sumberdaya alam (Alexander, 2002; Libosada, 2009), sehingga menjadi solusi konflik kepentingan pelestarian sumberdaya alam, ekonomi dan social (Barkauskiene and Snieska, 2013).

Tujuan umum penelitian ini adalah terpolanya peran kuadroheliks pariwisata (masyarakat, pelaku usaha wisata, pemerintah, perguruan tinggi) dalam pengelolaan berkelanjutan destinasi wisata gunung api bawah laut Mahengetang. Peran kuadroheliks berfokus pada item kegiatan ekonomi dan konservasi hasil analisis model ekonomi-ekologi yang 
dikembangkan tim peneliti. Secara khusus penelitian ini bertujuan untuk mengidentifikasi kondisi eksisting unsur ekonomi dan ekologi, analisis dan perumusan alternative kegiatan untuk peningkatan ekonomi dan ekologi berdasarkan indikator (WTP-WTA).

\section{Model analisis dan instrumen WTP-WTA}

Tahun 2012 penulis memformulasi model analisis untuk optimalisasi manajemen destinasi berkelanjutan. Model analisis ini dipolarisasi pada (1) kesediaan wisatawan membayar produk dan jasa pariwisata dan kompensasi terhadap konservasi, diperhadapkan dengan (2) kesediaan masyarakat lokal menyediakan produk, jasa dan kegiatan pelestarian sumberdaya (alam, social- budaya) kepada wisatawan. Model analisis diperlihatkan pada Gambar 1.

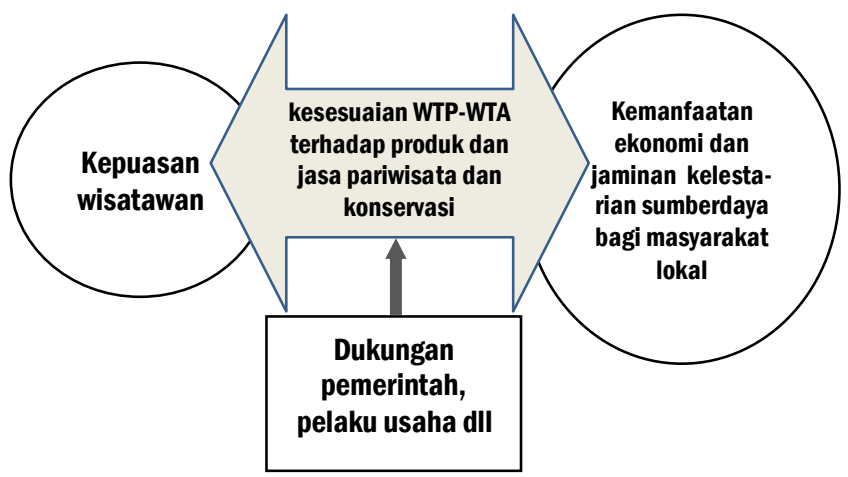

Gambar 1. Model analisis optimalisasi manajemen destinasi wisata berkelanjutan

Model analisis ini bersesuaian dengan asumsi yang dikemukakan oleh Scheyvens (1999), Wunder, (2000), Barkin (2003) bahwa kekuatan dan keberlanjutan ekowisata ditentukan terutama oleh interaksi wisatawan dengan masyarakat lokal. Selanjutnya, berdasarkan model analisis ini, dirancang instrumen untuk mengontrol: meningkatkan kesesuaian WTP-WTA dan mengarahkan produk dan kegiatan wisata pada peningkatan ekonomi dan/atau konservasi sumberdaya (alam dan social-budaya). Instrumen ini mencakup sejumlah indikator yang potensial dan realistik sesuai karakteristik destinasi. Diesendorf (2000), Stefanica and Vlavian-Gurmeza (2010), dan Barkauskiene and Snieska (2013) mengemukakan bahwa komponen dimana dapat dilakukan pengukuran indikator pembangunan berkelanjutan meliputi: ekologi, ekonomi, dan sosial. Terkait dengan penekanan konservasi, Kiss (2004) mengemukakan bahwa strategi konservasi terbaik harus didasarkan pada pilihan penilaian yang realistis dan fisibel terkait keefektifan biaya, dampak sosial dan keberlanjutan. Indikator lingkungan dapat menunjukkan masalah yang sedang berlangsung dan menjadi acuan untuk merumuskan tindakan korektif untuk pencegahan, pengendalian dan konservasi sumberdaya. Nghi et al (2007) mengemukakan bahwa indicatorindikator pembangunan berkelanjutan dapat dinyatakan dalam nilai-nilai kuantitatif atau semi-kuantitatif untuk mengukur tingkat adaptasi lingkungan, sub system sosial-ekonomi dan kebutuhan wisatawan. Instrumen kesesuaian WTP - WTA dibangun dari indikator-indikator pembangunan destinasi berkelanjutan yang diproyeksikan pada dimensi pertumbuhan ekonomi dan konservasi. Indikator yang dikembangkan berkaitan dengan permasalahan yang sedang berlangsung, dan produk atau kegiatan yang potensial dikembangkan untuk pertumbuhan ekonomi maupun konservasi sumberdaya (fisik, sosial-budaya). Tabel 1. adalah format pendataan WTP dan WTA atas indikator produk dan kegiatan yang memiliki dimensi ekonomi dan konservasi. 
Tabel 1. Format pendataan kompensasi ekonomi dan konservasi WTP-WTA (Pangemanan and Medellu, 2015)

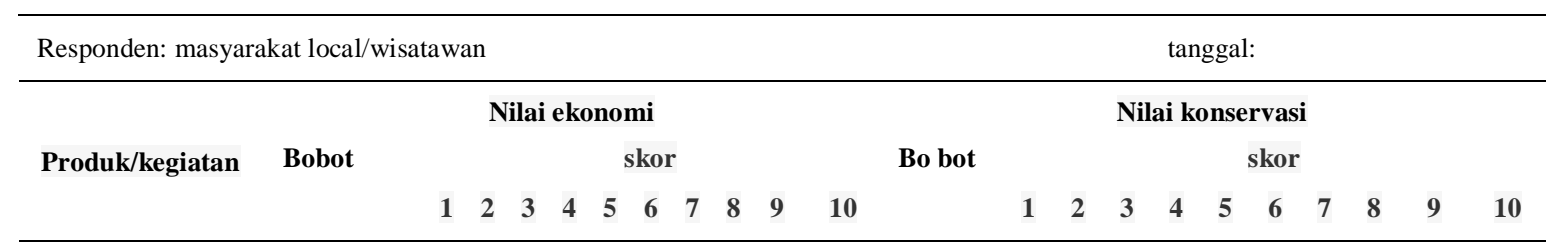

Catatan: skor 1: tidak setuju membayar atau menerima, skor 10: sangat setuju membayar atau menerima. Bobot 1: pri oritas terendah, bobot 5 prioritas tertinggi

\section{Pemetaan vektor WTP dan WTA dalam koordinat konservasi-pertumbuhan ekonomi}

Rataan data WTP dan WTA (dari seluruh indicator dan seluruh responden) yang diperoleh dari format di atas (Tabel-1), dipetakan sebagai besaran vektor dalam sistem koordinat konservasi-pertumbuhan ekonomi. Gambar-2 memperlihakan vektor WTP dan WTA dalam sistem koordinat dengan absis skor konservasi sumberdaya (fisik dan sosial-budaya) dan ordinat skor pertumbuhan ekonomi.

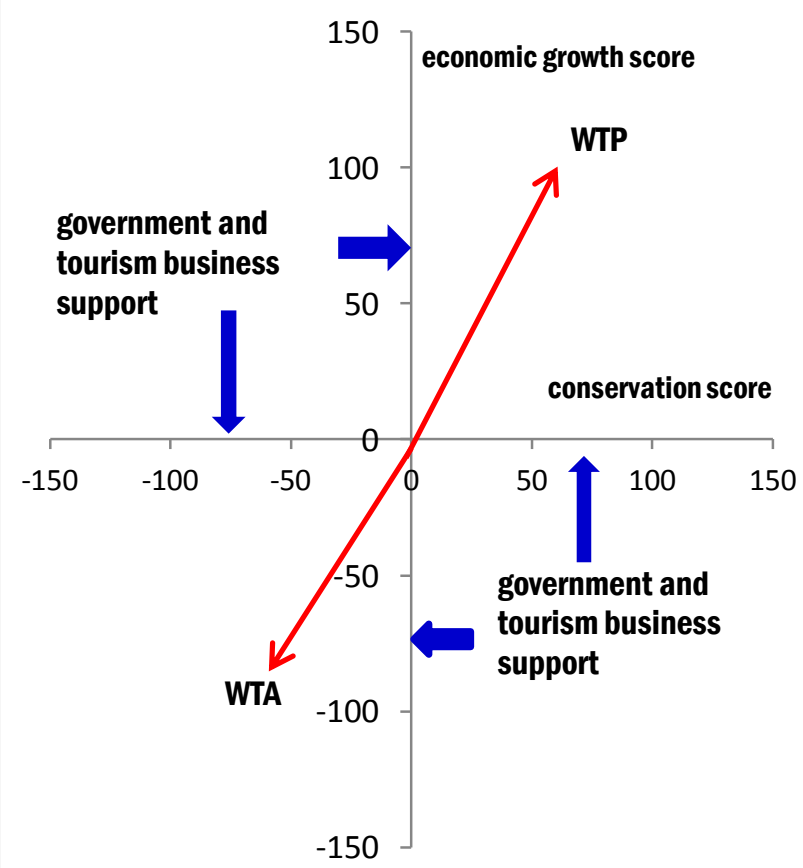

Gambar-2. Vektor WTP \& WTA dalam koordinat pertumbuhan ekonomikonservasi. Sumber: Pangemanan and Medellu, 2015
Titik pangkat vektor WTP dan WTA adalah posisi kondisi eksisting life cycle destinasi wisata. Ujung masing-masing vektor adalah skor (rataan) konservasi dan pertumbuhan ekonomi yang diperoleh menggunakan format pendataan WTP-WTA. Untuk mendeskripsikan kondisi eksisting, pendataan dapat dilakukan oleh peneliti atau oranglain berdasarkan fakta-fakta dari indikator konservasi dan pertumbuhan ekonomi. Instrumen juga dapat digunakan untuk mengsimulasi dampak konservasi dan pertumbuhan ekonomi berdasarkan pilihan kegiatan (jasa dan produk) yang dihendaki wisatawan (WTP) dan diterima masyarakat lokal (WTA), dengan dukungan pemerintah dan pelaku usaha. Besarnya dukungan pemerintah dan pelaku usaha terhadap WTP dan WTA didasarkan pada skor dukungan menurut indikator instrumen WTPWTA. Skor dukungan pemerintah dan WTA dikalikan dengan hasil perkalian bobot kegiatan dan skor pilihan wisatawan dan masyarakat, untuk menghasilkan skor komponen konservasi dan pertumbuhan ekonomi. Hasil simulasi ini penting untuk dijadikan acuan perencanaan dan pengendalian kegiatan yang menjamin keberlanjutan pemanfaatan sumberdaya. Tingkat kesesuaian WTP wisatawan dengan WTA masyarakat menentukan keterlaksanaan pilihan kegiatan. Tingkat kesesuaian 
diperoleh dari perkalian titik (dot product) vektor WTP dengan WTA. Nilai maksimum WTP.WTA adalah -1, menunjukkan potensi maksimum keterlaksanaan kegiatan yang dihendaki wisatawan dan diterima masyarakat. Tanda negatif menunjukkan kedua vektor berlawanan arah. Vektor WTP terletak di kuandran pertama dan vektor WTA di kuadran ketiga. Kolinieritas kedua vektor yang menunjuk potensi keterlaksanaan kegiatan dapat dikendalikan oleh peran pemerintah dan pelaku usaha. Tendensi kegiatan untuk penguatan komponen konservasi atau pertumbuhan ekonomi bergantung pada arah vektor WTP dan WTA. Jika vektor WTP dan WTA lebih dekat dengan sumbu konservasi, maka kegiatan akan lebioh memperkuat komponen konservasi, demikian sebaliknya. Arah vektor yang juga dapat dikendalikan oleh peran pemerintah dan pelaku usaha.

\section{Hasil Analisis Kuadrohelix Wisata Bawah Laut Gunung Api Mahengetang}

Pemetaan vektor dan hasil analisis potensi keterlaksanaan kegiatan/produk wisata Hasil identifikasi kegiatan yang telah dilaksanakan dan yang potensial dikembangkan di kawasan wisata Mahengetang berkaitan dengan konservasi dan peningkatan ekonomi meliputi 22 kegiatan (a.l. pencangkokan karang, pembersihan sampah plastic dll). Hasil penilaian 22 kegiatan yang telah ada mendeskripsikan kondisi eksisting vektor WTP dan WTA seperti pada Gambar-3 (anak panah berwarna merah). Hasil simulasi 22 kegiatan (termasuk 22 kegiatan yang telah ada) yang datanya diperoleh dari wisatawan, penduduk local, pemerintah dan pelaku usaha menghasilkan dua scenario. Skenario-1 ditunjukkan oleh anak panah berwarna hijau dan skenario-2 ditunjukkan oleh anak panah berwarna biru. Perbedaan skenario-1 dan skenario-2 terletak pada faktor dukungan pemerintah dan pelaku usaha. Dukungan pemerintah dan pelaku usaha terhadap pilihan kegiatan WTPWTA yang memberikan peningkatan/penguatan komponen konservasi, lebih besar pada skenario-1 dibanding skenario-2. Hasil pengujian kolinieritas vektor WTP - WTA untuk kondisi eksisting, skenario-1, dan skenario-2 masing-masing adalah - 0.89, - 0.94, dan - 0.96. Tingkat kolinieritas WTP-WTA pada kondisi eksisting sebesar - 0.98 menunjukkan bahwa interaksi wisatawan dengan masyarakat lokal dalam konservasi sumberdaya dan pertumbuhan ekonomi (pendapatan masyarakat lokal) sudah cukup baik, namun perlu ditingkatkan baik melalui produk dan kegiatan alternatif, serta dukungan pemerintah dan pelaku usaha. Pilihan kegiatan yang dihendaki wisatawan dan diterima masyarakat dengan dukungan pemerintah dan pelaku usaha menghasilkan tingkat persesuaian WTP dan WTA seperti pada skenario-1 dan skenario-2, yang lebih tinggi dari kondisi eksisting. Hasil ini menunjukkan bahwa penggunaan instrumen ini dapat meningkatkan produktivitas wisata serta jaminan konservasi sumberdaya alam, sosial-budaya). Hasil pemetaan vector menunjukkan bahwa skenario-1 merupakan pilihan yang paling besar mengkontribusi konservasi sumberdaya.

\section{KESIMPULAN}

Instrumen analisis WTP-WTA dapat menghasilkan pilihan kegiatan dan produk wisata yang dihendaki wisatawan dan diterima masyarakat setempat dengan 
dukungan pemerintah dan pelaku usaha. Pilihan kegiatan dan produk dapat menjamin pemanfaatan sumberdaya secara berkelanjutan, dengan memperkuat prinsip konservasi. Instrumen ini dapat diadaptasi untuk pengelolaan sumberdaya lainnya yang memperhadapkan kepentingan ekonomi, dan kelestarian lingkungan dan sumberdaya.

\section{DAFTAR PUSTAKA}

Alexander C. O'Neill. 2002. What Globalization Means for Ecotourism: Managing Globalization's Impacts on Ecotourism in Developing Countries. Indiana Journal of Global Legal Studies: 9(2): 501 - 528.

Barkauskiene K and V. Snieska. 2013, Ecotourism as an untegral part of sustainable tourism development. Economics and Management, 18(3): $449-456$

Barkin D. 2003. Alleviating poverty through ecotourism: Promises and reality in the Monarch butterfly reserve of Mexico. Environment, Development and Sustainability, 5: 371-382.

Ferraro, P.J. and Simpson, R.D. (2002) The cost-effectiveness of conservation payments. Land Econ. 78, 339-353

Ferraro, P.J. and Kiss, A. (2002) Direct payments to conserve biodiversity. Science 298: 1718-1719
Kiss A. 2004. Is community-based ecotourism a good use of biodiversity conservation funds?. TRENDS in Ecology and Evolution, 19 (5): $232-237$

Koens J.F., C. Dieperink, and M. Miranda. 2009. Ecotourism as a development strategy: experiences from Costa Rica. Environ Dev Sustain, 11:1225-1237

Libosada C.M. 2009. Business or leisure? Economic development and resource protection - Concepts and practices in sustainable ecotourism. Ocean \& Coastal Management 52: 390-394

Medellu Ch., and Pangemanan P., 2015. WTP-WTA instrument for controlling the tourism destination life-cycle. Paper presented at IcoMensed seminar, August 7 9,2015

Sangihe dalam Angka, 2013. Badan Pusat Statistik Kabupaten Kepulauan Sangihe.

Slinger-Friedman V. 2009. Ecotourism in Dominica: Studying the Potential for Economic Development, Island Studies Journal, 4(1): 3-24

Teguh F. 2014. Pedoman umum pembentukan forum tata kelola pariwisata. Dirjen Pengembangan Destinasi Pariwisata. Kementrian Pariwisata dan Ekonomi Kreatif

Wunder, S. 2000. Ecotourism and economic incentives: an empirical approach. Ecol. Econ. 32, 465-479 